\title{
INTERNATIONAL CRIMINAL COURT AND TURKEY
}

\author{
Hakan Karakehya*
}

\begin{abstract}
International Criminal Court (ICC) to serve for the trial of the most serious inhuman acts against the humanity was finally established on 1 July, 2002, following a difficult and tough process. Turkey has not recognised the judiciary power of ICC yet. However, Turkey harmonises its domestic law with the statute and makes the necessary legal amendments, which proves its intention to be a party to the statute. In this study, Turkey's current legal and political status before ICC will be examined and the conditions hindering Turkey's becoming a party to ICC as well as the conditions causing Turkey to refrain from accession will be analysed. We believe that, a detailed examination of Turkey's status before ICC, as an important state in terms of its geography, culture and population, will contribute to the literature on international law and provide a compact source of information to be taken as reference by the practitioners and researchers. Presentation of our own opinions based on a cause and effect relation by also benefiting from the different views in the doctrine will constitute the main method of this study.
\end{abstract}

INTRODUCTION

I. CURRent Political AND Legal Status of TURKey Before the

INTERNATIONAL CRIMINAL COURT ............................................................. 782

II. MAin CONDITIONS PROPELling TURKeY to BeCOME A PARTY to

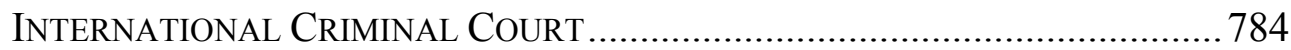

III. MAIN CONDITIONS CAUSING TURKEY TO REFRAIN FROM BECOMING A

PARTY TO INTERNATIONAL CRIMINAL COURT ..........................................785

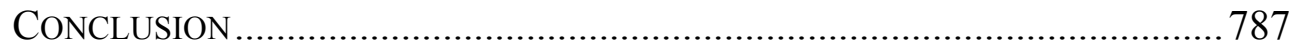

\section{INTRODUCTION}

In the history of humanity, the world has always witnessed wars, hostile acts of people towards each other. There may not be another creature which harms its own species that much. Observing these actions of people towards each other and against the humanity, some thinkers even asserted that human nature is essentially evil ${ }^{1}$.

"Evolutionary theory" is one of the principle approaches of 19th century, at the centre of social and political life. According to this theory, societies have to evolve and develop. Evolution is inevitable for a society

\footnotetext{
${ }^{*}$ Dr., Faculty of Law, Anadolu University, Chair of Criminal and Criminal Procedure Law, Eskişehir, Türkiye.

${ }^{1}$ Hobbes T., Leviathan, (Translated by Semih Lim) 127 (İstanbul 1995).
} 
and if there is evolution, there is always development, in other words a positive movement ${ }^{2}$. Acts of violence witnessed in the last century as well as the increasing number and variety of offenses against humanity have revealed that evolutionary theory has mistaken. Thus, the cruellest acts of violence and the most intense bloodshed than ever were observed in the last century ${ }^{3}$.

As a consequence, with the participation of many countries, Rome Statute was approved and opened to signature on $17 \mathrm{July}, 1998,{ }^{4}$ which is an important step for the establishment of a permanent international criminal court that will have jurisdiction over the most serious international crimes threatening the existence of international society as a whole and pricking everybody's conscience. Within this scope, it is decided through the ICC Statute that, jurisdiction of ICC embraced four categories of crimes which seriously hurt the conscience of international community and make states parties meet on a common ground. These are Genocide, Crimes against Humanity, War Crimes and Aggression. The statute includes exhaustive legal arrangements regarding these crimes, excluding aggression; furthermore the scope of three of these crimes is arranged in details through elements of crime adopted as an attachment to the statute ${ }^{5}$. The statute had remained open to signature until 31 December, 2000 and following the accessions and finalisation of the transposition process, the court's establishment process was finalised on 1 July, $2002^{6}$. Based on these developments, important steps have been taken in terms of universal protection of human rights.

Setting aside the discussions and doubts about its future position and its functionality, establishment of a permanent court of that kind is an important victory for humanity. Humanity has gained a great victory in fight against the most serious inhuman acts but this fight has not been finalised

\footnotetext{
${ }^{2}$ Marshall G., OXford Dictinory OF Sociology, (Evolutionism) 208 (Oxford New York 1998).

${ }^{3}$ Von Hebel H., An International Criminal Court-A Historical Perspective, ReFLECTIONS ON THE International CRiminal Court 13-4 (The Hague 1999). Karakehya H., Uluslararası Ceza Mahkemesi ve Uygulanabilir Hukuk, ANKARA ÜNIVERSITESI HUKUK FAKÜLTESI DERGISI, C.57, S.2., 135 (2008).

${ }^{4}$ England J. F., The Response of United States to the International Criminal Court: Rejection, Ratification or Something Else? Arizona Journal of InTERnATIONAL and COMPERATIVE Law, C.18, S.3, 941 (2001).

${ }^{5}$ Kirsch P., The Work of the Preparatory Commission, THE INTERNATIONAL CRIMINAL COURT: Elements of Crimes And Rules of Procedure And Evidence, xlvii (Roy S. Lee ed., New York 2001).

${ }^{6}$ Nuhoğlu A., Uluslararası Ceza Mahkemesi Tarafindan Uygulanabilecek Yaptırımlar, Uluslararasi CeZa Divani, 246 (Feridun Yenisey ed., İstanbul 2007). ATEȘ Ekşı C., Uluslararasi CEZA MAHKEMESININ İNSANLIĞA KARŞI SUÇLAR ÜZERINDEKI YARGI YETKISI 3 (Ankara 2004).
} 
yet $^{7}$. International society has an important task in enabling this court to serve functionally, and to obtain a status to judge not only those responsible for inhuman acts in III world countries, but also the citizens of developed countries, responsible for serious inhuman acts (especially, in the field of war crimes). However, the current situation achieved is also promising.

In this study, we aim to analyse the viewpoint of Turkey regarding the International Criminal Court established due to the above-mentioned reasons but whose judiciary power has not been recognised by Turkey yet, as well as the current legal arrangements in Turkey with regard to the court, and its future policies. Presentation of our own personal opinions based on a cause and effect relation by also benefiting from the different views in the doctrine will constitute the main method of this study.

\section{CurRent Political and Legal Status of Turkey Before the INTERNATIONAL CRIMINAL COURT}

Turkey has not become a party to the ICC yet. Turkey continuously monitored the drafting process of the statute and participated in the work but preferred not to become a party to the statute, because of several reasons to be examined in detail in the following parts and also has not recognised the judiciary power of the International Criminal Court. However, Turkey, closely monitoring the developments related with the court makes some important legal arrangements in its domestic law, indicating its preparation to become a party.

The most important one of these is the constitutional amendment in 2004, although Turkey is not a party to the statute. With this amendment, the provision: "No citizen shall be extradited to a foreign country on account of an offence" was amended as "No citizen shall be extradited to a foreign country on account of an offence except under obligations resulting from being a party to the International Criminal Court ${ }^{\natural,}$. Making such an amendment and expressly referring to the name of the court in a basic legal text reflect the future perspective of Turkey which has not recognised judiciary power of the court yet.

Moreover, Articles 76-78 of the Turkish Criminal Code (TCC) include arrangements on genocide and offenses against humanity; and matters with

\footnotetext{
${ }^{7}$ Kanbur N., Devletlerin Egemenlik Yetkisine Etkisi Bakımından Uluslararası Ceza Mahkemesi, EAKADEMI 26 (Nisan 2012).

${ }^{8}$ Yenisey F., Uluslararası Ceza Divanı Kabul Edildiği Takdirde Türk Uyum Kanunu Nasıl Düzenlenmelidir? UluSLARARASI CEZA DivANI 255 (Feridun Yenisey ed., İstanbul 2007).
} 
regard to these types of offences have mostly been aligned with the statute ${ }^{9}$. Besides, in line with the statute, TCC stipulates that, lapse is out of question for these offenses. However, it is remarkable that, TCC does not provide any exceptions to these offences in terms of some immunities such as legislative immunity, as different from the stature. Yet, the statute does not recognise any immunity with regard to the offences under the judiciary power of ICC.

At the end of 1990s, Turkey's becoming a party to ICC was debated but even those advocating Turkey's accession were also divided into two groups within themselves. First group was asserting that, Turkey should become a party forthwith as the arrangements in domestic law could be made more rapidly under international pressure. Those supporting this view argued that, the then-current bureaucracy would not allow Turkey to make any arrangements in the domestic law without assuming any obligation or would necessitate a long period of time. It was claimed that, after becoming a party to the statute, Turkey would have to accelerate and make such legal arrangements within a short while, because of the obligations assumed. On the other hand, the second group advocated that, if Turkey becomes a party before making necessary regulations in the domestic law, this would put Turkey in a tight spot and therefore, the domestic law should be aligned with the statute firstly before accession. Moreover, Turkey had bad experiences in this regard. Turkey recognised the judiciary power of European Court of Human Rights (ECHR) at the end of 1980s before making the necessary arrangements, and then surprised at the consecutive convictions in the next few years and tried to make the necessary arrangements in the domestic law rapidly without any preparation. Therefore, Turkey had to pay high amounts of compensations due to these convictions. Accordingly, they asserted that, in this case, if Turkey became a party to ICC before making the necessary arrangements, the possible convictions might not lead to compensations but convictions of many government authorities.

The process since then indicates that, the second view is more prominent. Above-mentioned legal arrangements point to Turkey's will of becoming a party to ICC, at least seemingly. However, Turkey does not want to face with the same surprises as in ECHR, and therefore, aims to align its domestic law and to get ready in terms of its bureaucracy.

\footnotetext{
${ }^{9}$ Çakmak C., \& Öztürk A., Türk Dış Politikası ve Uluslararası Hukuk: Türkiye-Uluslararası Ceza Mahkemesi Örneği, UluSLARARASI İLIŞKILERDE GÜNCEL KONULAR VE TÜRKIYE, 222 (Ankara 2012).
} 


\section{Main Conditions Propelling Turkey to Become A PARTY to INTERNATIONAL CRIMINAL COURT}

Since the Rescript of Gülhane (1839) in the Ottoman Period, Turkey has always faced the West and aimed to gain ground among the European societies. Even though there is a tendency to protect the cultural characteristics, Europe's advancement in the fields of science and technology in the modern period has generally been appreciated by the Turkish society. Therefore, gaining ground among the European societies has been among the most prominent social objectives of Turkey nearly in the last two hundred years. Currently, this objective is materialised as accession to the European Union (EU). Recently, membership to the EU is among the main political and social agenda items in Turkey. The developments in the negotiation process of Turkey which is now a candidate country are monitored by a significant part of the society and these developments are even exploited politically at times.

In this regard, EU accession process has had an important effect on the alignment of Turkish legal system with the content of the European Convention on Human Rights since the beginning of 1990s. We believe that, this also applies to Turkey's becoming a party to ICC. Thus, all of EU Member States have recognised the judicial power of ICC. The future members of the EU are also expected to act accordingly ${ }^{10}$. Therefore, considering that accession to the EU is an important objective of Turkey and that all EU Member States are a party to ICC, Turkey's becoming a party to ICC will not be surprising depending on the solution of the problems mentioned in the following parts.

Moreover, Turkey's becoming a party to ICC is a significant matter in terms of its international prestige, as a state which is a party to ICC indicates its self-confidence in the international arena. In fact, none of the states would like to have its citizen being judged before an international court. Besides it is displeasing for modern states to allow its citizens to be judged before international justice because of its unwillingness or incapability to judge. On the other hand, by recognising the judiciary power of a court, that may judge its citizen, the state gives two important messages to the international society. First one is that, my country and the citizens under my authority cannot easily be related with such kind of serious inhuman actions and therefore, the author can readily become a party. Second message is that, even if any of my citizens or government authorities has engaged in such

\footnotetext{
${ }^{10}$ Çakmak C., \& Öztürk A., Türk Dış Politikası ve Uluslararası Hukuk: Türkiye-Uluslararası Ceza Mahkemesi Örneği, UluSLARARASI İLIŞKILERDE GÜNCEL KONULAR VE TÜRKIYE, 218 (Ankara 2012).
} 
actions, the author can sentence them duly and prevent any need for the judiciary power of ICC as a complementary court. When the states currently refraining from becoming a party to ICC are considered, it is seen that, they really have great problems preventing them to display such self-confidence. Accordingly, Turkey's becoming a party to ICC will give the message to the international society that Turkey is a country respecting human rights and fighting against the most serious inhuman actions duly and will also prove its self-confidence.

\section{MAIN CONDITIONS CAUSING TURKEY TO REFRAIN FROM BECOMING A PARTY TO INTERNATIONAL CRIMINAL COURT}

The idea of establishing a permanent international criminal court has not emerged recently ${ }^{11}$. Although there have been many attempts in this regard for a long time, the establishment process of this court could have been finalised only at the beginning of $2000 \mathrm{~s}^{12}$. One of the most important reasons of such a long delay is that, it is difficult especially for modern states to leave behind the classical understanding of sovereignty. Actually, during the establishment process of the court, the nation states strongly refrained from the idea of intervention to their own judicial power in the criminal matters, even if this is related only with certain actions and necessitates certain conditions ${ }^{13}$. Despite these, parties finally arrived at an agreement and upon the establishment of a permanent international criminal court, international law has begun to address the criminal law which had been the single national field of law in the nation states, that international law could not intervene fully. It would not be wrong to state that, this classical understanding of sovereignty is currently prevailing in Turkey ${ }^{14}$. Moreover, it is still very displeasing for Turkish politics and bureaucracy that, Turkey would let its citizen to be judged before an international court. One of the reasons that cause Turkey to refrain from becoming a party to the court is that classical understanding of sovereignty is still effective on bureaucracy and politics in Turkey.

Besides, status of Turkish Republic of Northern Cyprus (TRNC) is among the reasons causing Turkey to refrain from becoming a party to the

\footnotetext{
${ }^{11}$ Alpkaya G., Eski Yugoslavya İçin Uluslararasi CeZa Mahkemesi 1 (Ankara 2002).

${ }^{12}$ Uzun E., Milletlerarası Ceza Mahkemesi Düşüncesinin Tarihsel Gelişimi ve Roma Statüsü, ANADOLu ÜNIVERSITESI SOSYAL BILIMLER ENSTITÜSÜ DERGISI S.2, 23 (2003).

${ }^{13}$ Pierson C., Modern Devlet, (Translated by Dilek Hattatoğlu) 24 (İstanbul 2000).

${ }^{14}$ Çakmak C., \& Öztürk A., Türk Dış Politikası ve Uluslararası Hukuk: Türkiye-Uluslararası Ceza Mahkemesi Örneği, UluSLARARASI İLIŞKILERDE GÜNCEL KONULAR VE TÜRKIYE, 219 (Ankara 2012).
} 
court $^{15}$. At present, TRNC which is recognised by Turkey as a separate state and which hosts Turkish troops as its guarantor state has not been recognised in the international arena yet. Therefore, Turkey is justifiably doubtful about the possibility that, Southern Cyprus may apply to the ICC claiming that, Turkey is occupying the island. Thus, in this case, many politicians and bureaucrats may be judged before the court. Perhaps the most important reason of Turkey's refraining from becoming a party to the court is the currently indefinite status of TRNC. In our opinion, it is not possible for Turkey to become a party to the court before solving the Cyprus issue. Now, the necessary legal arrangements are being made but even the finalisation of these arrangements is not enough alone for Turkey to become a party to ICC before the Cyprus issue is solved. However, it may be asserted that, the actions of Turkey only after accession fall within the judicial power of ICC and therefore, Turkey's concerns are groundless. Nevertheless, it is not unlikely that, the Turkish troops in TRNC are considered by ICC under the framework of on-going/continuous offense and that the legal proceedings will be initiated on this basis.

Another reason preventing Turkey to become a party to ICC until now is the PKK issue ${ }^{16}$. PKK recognised as a terrorist organisation in the Turkish national law as well as in the international arena is an organisation structured both within and outside Turkey. Although it is internationally recognised as a terrorist organisation, a significant part of the international society considers this organisation as peace fighters defending the rights of Kurdish people. Therefore, it can easily maintain its structuring process in many states other than Turkey. Main body and centre of the organisation is in Quandil Mountains in Northern Iraq. With the aim of destroying this structure there, Turkey conducts trans-boundary air and ground attacks, occasionally. Although these trans-boundary operations have not been frequent in the recent times due to the "solution process" rapidly progressing in the last few years, the future is indefinite. Accordingly, based on the possibility of continuance of these operations, political authorities and members of the Turkish Armed forces (TSK) may be judged before the ICC. This causes Turkey to think twice before becoming a party to the court. Particularly TSK is closely monitoring the developments since the beginning of the establishment process of ICC. It is seen that, TSK advises an important part of its members carrying out academic studies to work on ICC. Therefore, it is not surprising that, most of the studies regarding ICC

\footnotetext{
${ }^{15}$ Bozbayindir A. E., TURKey AND InTERnATIONAL CRiminal Court 34 (Baden Baden 2012).

${ }^{16}$ Bayıllıoğlu U., Uluslararası Ceza Mahkemesi ve Türkiye, ANKARA ÜNIVERSITESI HUKUK

FAKÜLTESI DERGISI, C.56, S.1, 63 (2007).
} 
have been carried out by the military personnel. Thus, if Turkey becomes a party to ICC, members of TSK are among the first to be judged before the Court due to the above-mentioned concerns. Accordingly, TSK is one of the principal organisations rightfully doubtful about Turkey's becoming a party to ICC, as it does not want to assume such a risk for its members. When the effect of TSK on Turkish bureaucracy and politics is considered, the effect of TSK stance on Turkey's decision would also become clearer.

Finally, it should also be noted that generally the African origin citizens of III world countries are judged before ICC. Academic circles ironically call ICC as "International African Criminal Court". This can be explained partially with the fact that, human rights are not reached the desired level in these regions. However, considering that many of the mass deaths in states like Afghanistan, Libya, and Iraq are resulting from the interventions of developed countries, the fact that none of the citizens of developed countries has been judged before the court debases the status of ICC among the Turkish public opinion. Therefore, because of these problems, the public support to propel the slow-acting political authorities to become a party to ICC cannot be ensured.

\section{CONCLUSION}

Following a difficult historical process, establishment of a permanent international criminal court was finalised on 1 July, 2002. Establishment of this permanent court is a victory of humanity in terms of the fight against the most serious inhuman actions. Currently, Turkey has not recognised the judiciary power of this court. However, certain important legal arrangements made in the domestic law, indicate that, Turkey is getting ready to become a party in the future. Amendment of the Article 38 of the constitution of the Republic of Turkey stipulating that, no citizen shall be extradited to a foreign country because of an offence, and including genocide and offenses against humanity in the Turkish Criminal Code in line with the stature are among the most important of these amendments.

There are reasons propelling Turkey to become a party to ICC. These can be listed as follows: Since the Rescript of Gülhane (1839) in the Ottoman Period, Turkey has always faced the West and aimed to gain ground among the European societies. Currently, this objective is materialised as accession to the European Union (EU). Therefore, considering that accession to the EU is an important objective of Turkey and that all EU Member States are a party to ICC, Turkey's becoming a party to ICC will not be surprising depending on the solution of the problems 
mentioned in the following parts.

Moreover, Turkey's becoming a party to ICC is a significant matter in terms of its international prestige as this will give the message to the international society that Turkey is a country respecting human rights and fighting against the most serious inhuman actions duly and prove its selfconfidence.

However, there are also conditions causing Turkey to refrain from becoming a party to ICC. These are as follows: Firstly, it would not be wrong to state that, this classical understanding of sovereignty is currently prevailing in Turkey. Moreover, it is still very displeasing for Turkish politics and bureaucracy that Turkey would let its citizen to be judged before an international court.

Besides, status of Turkish Republic of Northern Cyprus (TRNC) is among the reasons causing Turkey to refrain from becoming a party to the court. As a guarantor state, Turkey deploys its troops in the island and accordingly, it is doubtful about the possibility that, Southern Cyprus may apply to the ICC claiming that Turkey is occupying the island. Thus, in this case, many politicians and bureaucrats may be judged before the court. In our opinion, it is not possible for Turkey to become a party to the court before solving the Cyprus issue.

Another reason preventing Turkey to become a party to ICC until now is the PKK issue. Main body and centre of the organisation is in Quandil Mountains in Northern Iraq. With the aim of destroying this structure there, Turkey conducts trans-boundary air and ground attacks, occasionally. Accordingly, Turkey is disturbed with the possibility that members of the military and politicians will be judged before ICC if it will be necessary to continue these attacks in the future, and if it is a party to ICC, then.

Finally, it should also be noted that, generally the African origin citizens of III world countries are judged before ICC. However, considering that many of the mass deaths in a number of states are resulting from the interventions of developed countries, the fact that none of the citizens of developed countries has been judged before the court debases the status of ICC among the Turkish public opinion. Therefore, because of these problems, the public support to propel the political authorities to become a party to ICC cannot be ensured. 